\title{
Occupational dermatosis
}

\author{
Dermatoses ocupacionais
}

\author{
Alice de Oliveira de Avelar Alchorne ${ }^{1}$ \\ Marzia Macedo Silva ${ }^{3}$
}

\author{
Maurício Mota de Avelar Alchorne ${ }^{2}$
}

\begin{abstract}
Occupational Dermatosis is described as any alteration in the skin, mucosa or annexes that is directly or indirectly caused, conditioned, maintained or aggravated by agents present in the occupational activity or work environment. The authors of the present study describe the importance of the topic and the epidemiology and etiopathogeny of the main forms of occupational dermatoses: allergic and irritative contact dermatitis, phytodermatitis, acne (elaioconioses and chloracne), keratosis, cancers, foreign body granuloma, infections, onychias, and ulcerations.

Clinical findings of occupational dermatosis are presented in relation to various professions. Laboratory tests used to diagnose this condition are analysed, with special emphasis on patch testing, which is the gold standard. Information about the treatment and prevention of this disorder is provided. Collective and individual measures, especially regarding the proper use of individual protection equipment for the prevention of occupational dermatosis, are detailed.

Keywords: Barbering; Chloracne; Dermatitis, contact; Dermatitis, occupational; Keratosis

Resumo: Dermatose ocupacional é qualquer alteração da pele, mucosa e anexos, direta ou indiretamente causada, condicionada, mantida ou agravada por agentes presentes na atividade ocupacional ou no ambiente de trabalho. Os autores referem a importância do tema, a epidemiologia e a etiopatogenia das principais dermatoses ocupacionais: dermatites de contato irritativas e alérgicas, fitodermatites, acnes (elaioconiose e cloracne), ceratoses, cânceres, granulomas de corpo estranho, infecções, oníquias e ulcerações. A clínica da dermatose ocupacional é apresentada em diferentes profissões. Analisam-se os exames laboratoriais pedidos nessas dermatoses, com especial destaque para testes de contato, que são o padrão ouro, e fornecem-se dados do tratamento e prevenção; quanto à prevenção da dermatose ocupacional, informam-se as medidas coletivas e individuais, especialmente, no que respeita ao uso adequado dos equipamentos de proteção individual.

Palavras-chave: Barbearia; Ceratose; Cloracne; Dermatite de contato; Dermatite ocupacional
\end{abstract}

\section{INTRODUCTION}

The objective of this work is to review most occupational dermatoses (OD), presenting their definition, epidemiology, and clinical symptoms to draw attention to the importance of an accurate diagnosis.

Occupational dermatosis is any alteration in the skin, mucosa, and annexes, which is direct or indirectly caused, conditioned, maintained or aggravated by agents present in the occupational activity or work environment. ${ }^{1,2,3,4,5,6}$

\section{EPIDEMIOLOGY}

Epidemiologic studies about occupational dermatosis in Brazil are rare. There is no compulsory notification of the disorder and subdiagnosis is frequent as many workers do not seek health services fearing loss of their jobs and salaries. In industrialized countries, OD corresponds to $60 \%$ of the occupational diseases. Chemical agents are the most important and frequent causes of OD. ${ }^{1,78}$ In the Western world, about $90 \%$ of OD are contact dermatitis (CD), ${ }^{9,10}$ and

\footnotetext{
Approved by the Editorial Board and accepted for publication on December $7^{\text {th }}, 2009$.

* Work conducted at Nove de Julho University (UNINOVE) and Faculty of Medicine of ABC - Sao Paulo (SP), Brazil.

Conflict of interest: None / Conflito de interesse: Nenhum

Financial funding: None / Suporte financeiro: Nenhum

Associate Professor of Dermatology at Nove de Julho University (UNINOVE) - Sao Paulo (SP), Brazil.

Associate Professor of Dermatology at Nove de Julho University (UNINOVE) - Sao Paulo (SP), Brazil.

M.S. in Health Sciences from the Federal University of Sao Paulo (Unifesp) - Sao Paulo School of Medicine - Sao Paulo (SP), Brazil.

(C)2010 by The Brazilian Annals of Dermatology
} 
its frequency is increasing due to contact with new products. In the work area, irritative contact dermatitis (ICD) is more frequent than allergic contact dermatitis (ACD), with a 4:1 ratio. ${ }^{5}$ In general, hands are more affected by CD due to the manipulation of many substances and excessive humidity and friction. Most cases of $\mathrm{CD}$ are not severe, but they often cause discomfort, pruritus, wounds, traumas, aesthetic and functional alterations that interfere with social and professional life. Prevalence of occupational skin cancer is not well researched because it is difficult to establish a causal relationship (outside of work exposure, long latency period, use of various chemicals).

\section{ETIOPATHOGENY}

Occupational dermatosis is determined by the interaction of two groups of factors:

Indirect or predisposing causes, such as age, race, gender, morbid antecedents and concomitant diseases such as pre-existing dermatosis (atopic dermatitis ${ }^{11}$ ), environmental factors such as climate (temperature, humidity), easy acces to hygiene and cleanliness;

Direct causes constituted by biological, physical, chemical or mechanical agents found in the work environment, which would act directly on the skin and cause or aggravate a pre-existing dermatosis.

\section{INDIRECT CAUSES}

It is known that young individuals are more affected by OD due to work inexperience and thinner epidermis. The incidence of occupational contact dermatitis decreases with professional training ${ }^{1,8}$, it is less common in black individuals, and it occurs more in men than women (79\%:21\%). Yellow and black individuals have more protection from the degenerative effects of the sun's ultraviolet rays, but the latter develop keloids more frequently.

Sensitizing substances vary according to gender. For men the most frequent are found in cement and in the rubber used in individual protective equipment (IPE). Generally, the most common sensitizing agent for women is the nickel found in costume jewelry, which is often disabling for various occupations. Pre-existing dermatosis may facilitate the penetration of sensitizing agents. Workers who are often in contact with cleaning products are at greater risk of developing $\mathrm{CD}$.

\section{DIRECT CAUSES}

Occupational dermatosis may be caused by a variety of chemical, physical or biological agents in the workplace. The most common are: metals, acids and alkalis, aromatic hydrocarbons, lubricating and cutting oils, arsenic (chemical); radiation, trauma, vibra- tion, pressure, heat, cold (physical); ${ }^{12}$ viruses, bacteria, fungi, parasites, plants, animals (biological). Psychic alterations may lead to the self-induction of lesions (dermatitis artefacta) for the obtainment of a benefit. ${ }^{13}$

The inflammatory process of ICD starts when the agent (alkalis, acids, and solvents) enters in contact with the skin and causes a lesion in the corneal skin layer, leading to an increase in permeability and allowing the passage of substances that harm keratinocytes, ${ }^{14}$ producing inflammatory cytokines that stimulate other cells. In ACD, the inflammatory reaction is of immunologic type IV (cellular immunity) and it occurs in three phases: a) induction or immunization or sensitization; b) elicitation or development; c) resolution (end of the inflammatory reaction). ${ }^{15,16}$

It may be difficult to establish an occupational relationship with skin cancer. The main occupational carcinogenic agents are: physical - ionizing and nonionizing radiation (X-rays, ultraviolet and infrared rays) and trauma; chemical - inorganic arsenic (pesticides and environmental contamination), aromatic hydrocarbons, nitrosamines (cutting fluids); biological (HPV virus).

\section{CLASSIFICATION AND CLINICAL SYMPTOMS}

\section{Contact dermatitis}

Cases of CD are classified into ICD and ACD. ${ }_{17,18,19}$ Irritative Contact Dermatitis is the most important form of the disease among OD due to its frequency $(80 \%$ of $C D)$. Lesions appear after successive or non-successive exposures to the irritating substance and are restricted to the contact areas. Lesions also appear based on frequency and length of exposure. Irritative contact dermatitis can be caused by a relative or absolute irritant agent (Figures 1 and 2). A relative irritant agent leads to the gradual appearance of lesions after successive exposures, whereas an absolute irritant causes the immediate appearance of lesions. Depending on its concentration, the same substance can be an absolute irritant agent (high concentration) or relative agent (low concentration). A single exposure of prolonged duration may also induce absolute irritation. When hands are affected, lesions appear more commonly in the dominant hand and are more frequent in the palmar region.

In allergic contact dermatitis, lesions occur in areas that were exposed to the sensitizing substance, where they are more intense; however, they can also develop in areas that were not in contact with the sensitizing agent and be disseminated. After previous exposure, lesions appear within variable periods of time, but at least a week is necessary for sensitization. 
They can appear after months or years of contact. Allergic contact dermatitis can develop abruptly after previous contact with the sensitizing agent. The intensity and extension of lesions may aggravate and lesions may appear more rapidly at every re-exposure. $17,18,19,20,21$

Irritative contact dermatitis facilitates the development of an allergic reaction (ACD). ${ }^{2}$

\section{Eczematous CD}

Eczematous lesions can have acute (erythema, edema, vesicles, blisters, and exudation), sub-acute

(exudation and crusts), and chronic evolution (xerosis, scaling, keratosis, infiltration, lichenization, and fissures). Normally, relative ICD is chronic and absolute ICD is acute, and the latter manifests itself as a "burn" with: erythema, edema, necrosis, blisters, crusts, and ulcerations. Allergic contact dermatitis can have three stages of evolution. Photodermatitis is caused by phototoxic agents and resembles absolute ICD (citric fruit pulp) ${ }^{23}$ or by photoallergic agents with ACD aspect (drugs modified by ultraviolet light), and predominates in exposed areas. ${ }^{24,25}$

\section{Non-eczematous CD}

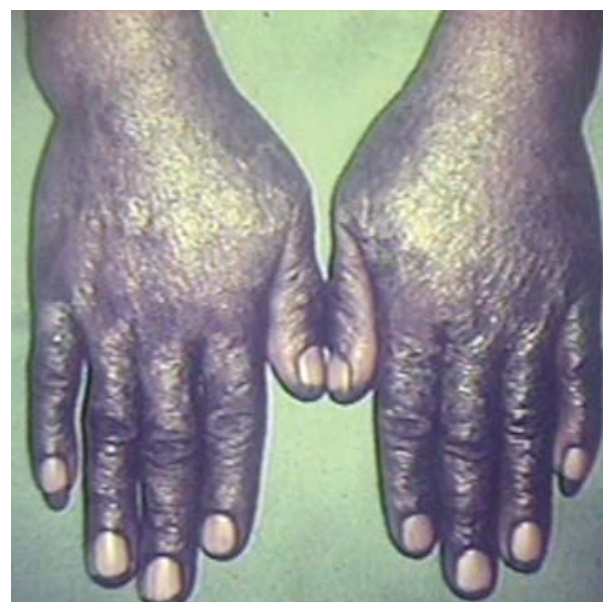

FIGURE 1:

Relative contact dermatitis by primary irritant caused by solvents in a gast station worker

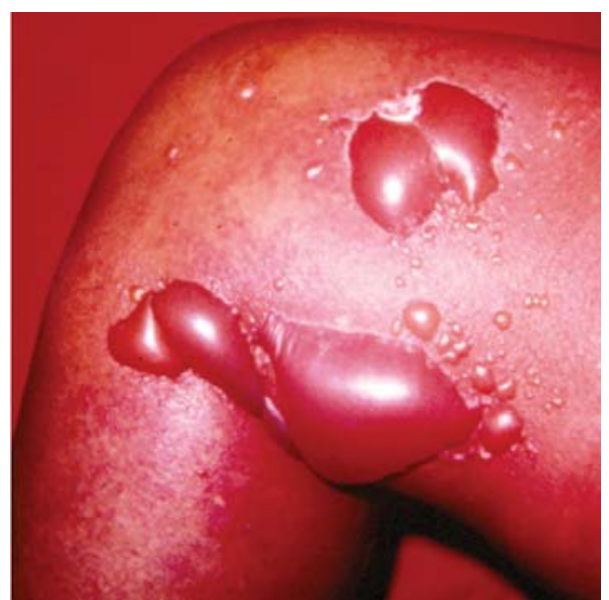

Figure 2: Absolute irritative contact dermatitis caused by sodium hydroxide in a maid
It occurs more rarely. The more frequent ones are: dishydrosis (metals, cutting oils); lichenoid contact dermatitis (photo developing solution, epoxy resins, $\mathrm{Ni}$, and $\mathrm{Cu}$ ); non-immunologic and immunologic contact urticaria (mediated by IgE), which occur minutes after contact (latex, food, plants, medicine, preservatives, fragrances) ${ }^{26}$; chemical vitiligo - contact leukoderma (hydroquinone); purpuric contact eruption (rubber products and laundry bleachers); polymorphous erythema - contact simile (plants, wood, drugs, and pesticides); pustular eruption (metals and ointments); keratosis contact dermatitis (ACD caused by rubber); post-eczematous or non-post-eczematous hyperchromic CD (creams, oil preservatives, perfumes, colorings, wood, laundry detergents, and lime). ${ }^{23}$

\section{Other occupational dermatoses}

2.1. Acne: elaioconiosis - occurs in exposed areas or areas covered by dirty clothes, a frequent situation for metal workers (cutting oils) and mechanics (grease); chloracne - severe occupational acne, caused by environmental contamination or industrial use of chlorate hydrocarbons, found in agricultural defense agents (Figure 3). They occur due to obstruction of pilous follicles, with irritation and secondary infection. $^{27}$

2.2. Keratosis: traumatic and pre-cancerous (solar, arsenical, and caused by cutting oils) (Figure 4).

2.3. Cancers: are related to physical, viral and chemical agents. Basal cell and spinocellular carcinoma are the most frequent and often appear as papular, nodular-tumoral and/or ulcerated lesions in exposed areas. Melanomas may occur in rare cases. The association between lymphomas (especially T-cell) and chronic actinic dermatitis is controversial.

2.4. Foreign body granuloma: plants, metal shavings, and human and animal hair - "pilous fistula" ${ }^{28}$ (Figure 5).

2.5. Infections: It is usually difficult to establish an occupational relationship (risks outside of occupation). Diseases such as cutaneous erysipeloid (butcher), carbuncle or anthrax and milker's nodule (cattle raiser), and sporotrichosis (florists) are essentially occupational.

2.6. Onychias: infectious, traumatic, and dyschromic (melanonychia and leuconychia) (Figure 6).

2.7. Ulcerations: unspecific (work accidents) and specific (infectious).

\section{COMPLICATIONS}

Complications are related to each OD. The main complications are: secondary infections, seque- 


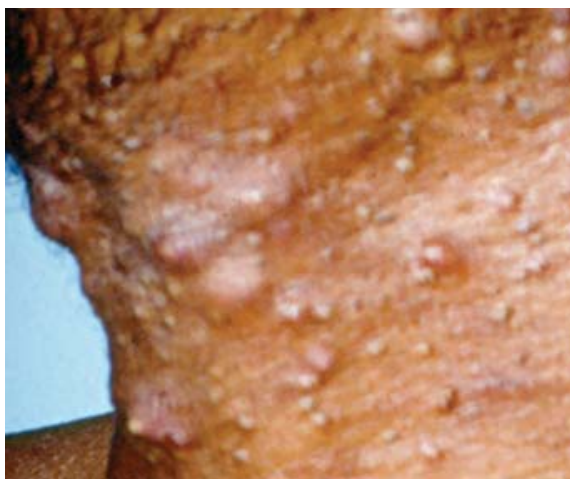

Figure 3: Chloracne

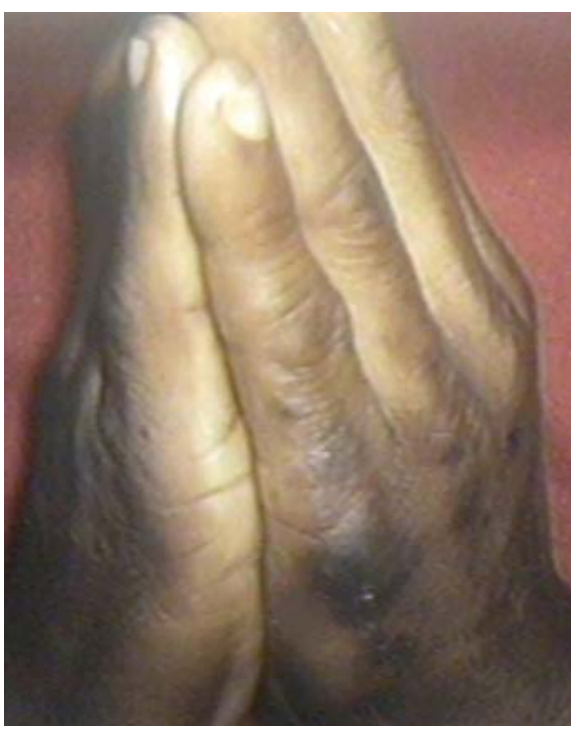

Figure 4: Callosity in the lateral region of the right hand of a car-waxing worker

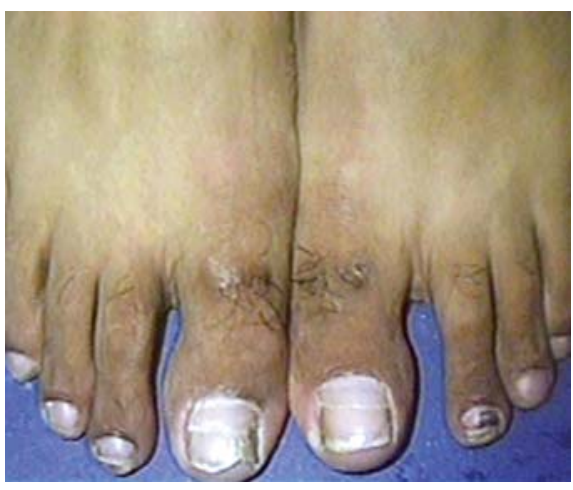

FIGURE 5: Foreign body granuloma caused by animal hair fragments in hair shearer (pilous fistula)

las (hyperchromia, hypochromia, and scars), performance decline and professional disability. Pre-cancerous keratosis and occupational cancers show complications specific to the malignancy of each histological type, mainly ulcerations, bleedings and metastization. Occupational infections may present complications typical of each agent's pathogenicity and localization.

\section{Occupational dermatitis in civil construction workers} Civil construction has more than two hundred occupations. In general, masons show ICD and 50\% of them develop ACD, especially due to their working conditions and lack of individual protective equipment. ${ }^{29}$ The risks are contaminating metals present in cement (such as hexavalent and cobalt), vulcanizing agents used in rubber gloves (thiurane, carbamates, mercaptobenzothiazole, paraphenylenediamine, hydroquinone) ${ }^{30}$ and wood. Dry skin and the presence of ICD facilitate sensitization. Individual protective equipment made of rubber may cause ICD (sweat, $\mathrm{pH}$ of gloves, product irritants), ACD (rubber vulcanizers) and contact urticaria (mediated by IgE, by latex). Cement dust is extremely irritative (alkaline, hygroscopic and abrasive). When it is wet $(\mathrm{pH}>12)$, it becomes more irritant and may cause relative or even absolute ICD (when it remains for a long time under pressure, friction, and occlusion), leading to burns with blistering, necrosis and "cement ulcerations" ${ }^{31,32,33}$ (Figure 7). The basic composition of cement (silicates, calcium aluminates, iron and magnesium oxides, alkalis, and sulphates) is not sensitizing, but since it is contaminated with allergy-causing metals coming from its preparation, it may cause ACD. ${ }^{34}$

\section{Occupational dermatitis in health professionals}

In the area of health, OD is very common and it often affects the hands.

Physical, infectious and chemical dermatosis can occur. ${ }^{7}$ Humidity in the work environment predisposes these workers to OD. Allergic contact dermatitis is caused by working materials (gloves, metals, epoxy and acrylic resins) and other chemicals; for example, disinfecting agents for hygiene such as glutharaldeides 35 and drugs, that may also be irritants. Urticaria caused by latex in gloves is not rare ${ }^{20}$ and additives used in the vulcanization process of rubber gloves (dialkyl thioureas) have been considered the most common sensitizing agents for health professionals ${ }^{36}$. Drugs are no longer the main sensitizing substances.

In some countries these professionals represent the largest occupational group and most OD cases studied in these workers are those related to Medicine and Odontology. The types of dermatoses and their incidence vary according to the professional category; they also vary based on the different exposures of radiologists, clinical doctors, surgeons, or laboratory workers within the medical-odontological field. The most susceptible professionals are nurses and members of the surgical center team due to the use of many irritating substances (antiseptic), followed by dentists. It is estimated that 5 to $10 \%$ of these professionals are allergic to latex.

\section{Occupational dermatosis in beauty professionals}

There are many professional activities in the area of beauty and it represents the second largest entrepreneurial sector in number of workers in Brazil. 


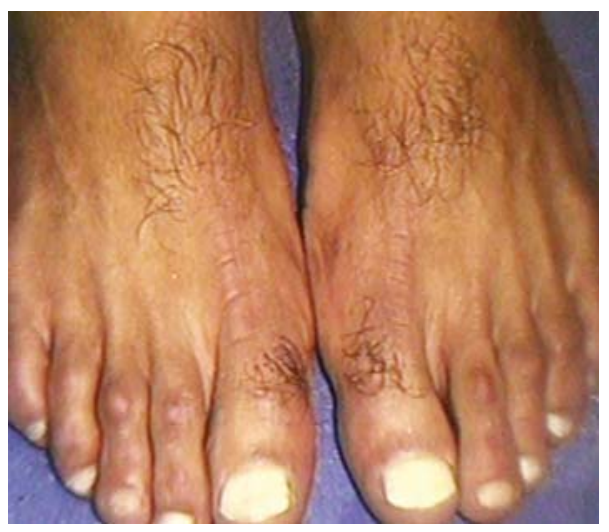

FIGURE 6: Occupational leukonychia caused by methahemoglobinemia in textile dyes

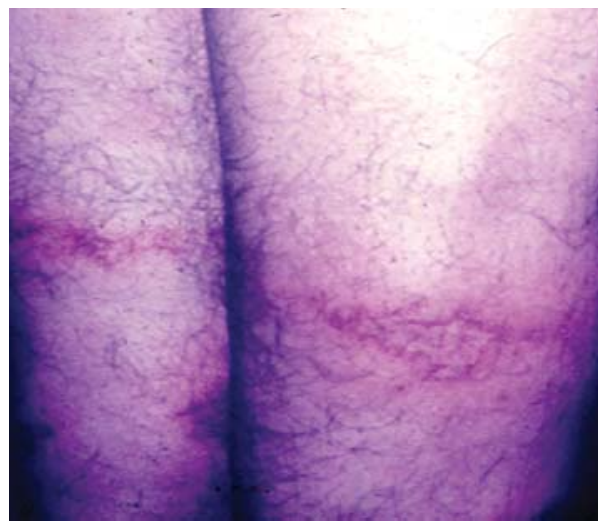

FIGURE 7: Absolute irritative contact dermatitis caused by wet cement ("cement ulcerations")

Allergic contact dermatitis affects nearly $50 \%$ of hairdressers; assistants and apprentices more often show ICD due to the humidity present in their work environment. Since hairdressers perform several activities, these professionals enter in contact with many products and the greatest risks are irritative agents: shampoos, hydrogen peroxide, ammonium persulfate, which accelerates hair discoloration, materials with increased humidity, hot air, and gloves. ${ }^{37}$ The most sensitizing substances are: metals ( $\mathrm{Ni}$ and $\mathrm{Co}$ ); pphenylenediamine present in hair days dyes and henna tattoos; sodium thioglycolate of products used in hair waving and straightening; rubber latex and vulcanizers used in rubber gloves; fragrances, creams with preservatives (formaldehyde); nail polish, nail prosthesis and acrylic glue, cosmetics (metildibromo glutaronitrile) ${ }^{38,39}$

\section{Occupational Dermatitis in Metallurgical Professionals}

In the metallurgical industry, the most common types of OD are ICD due to cutting fluids and, less frequently, ACD due to metal galvanizing (Figures 8 and 9) and cutting fluids (Figure 10). Occupational acne may occur in rare cases - elaioconyosis caused by oils ${ }^{40}$, and chloracne caused by chlorate hydrocarbons. ${ }^{41}$
Occupational dermatitis in the food service industry professionals

In the food service industry, workers that manipulate foods may develop OD due to contact with irritative and sensitizing agents and because they work in a humid environment. In bakeries and patisseries: flour, sweeteners, emulsifiers, foamers, bleachers, baking powder, flavorings, colorings; in the kitchen: work with materials with increased humidity and irritative (fruit, seasonings); ${ }^{42}$ sensitizing (garlic, onion) ${ }^{43}$ and photosensitizing foods (orange and lime peels, celery). ${ }^{44}$

\section{Occupational dermatitis in the cleaning service industry professionals}

In the cleaning sector, ICD is common because of humidity and soaps and detergents that contain fatty acids and alkalis. ${ }^{45}$ Cleaning products and gloves made out of rubber are the sensitizing agents. Enzymatic detergents rarely cause CD. ${ }^{20}$

\section{CLINICAL DIAGNOSIS}

It is important to consider the following aspects in the diagnosis and establishment of appropriate medical conducts to treat confirmed or suspected cases of OD:

Clinical symptoms;

History of occupational exposure, observing the concurrence between the onset of symptoms and the start of exposure, as well as the localization of lesions in areas exposed to suspected agents;

Improvement with work withdrawal and aggravation upon return to work.

\section{LABORATORY DIAGNOSIS}

Laboratory exams may contribute to the diagnosis of OD; however, none of theses resources can substitute a good anamnesis, a careful physical examination, and knowledge on the part of the professional individual about the main substances present in the work environment and the risks they offer.

The patch test (PT) is the main laboratory resource which allows the differentiation between ICD and ACD. ${ }^{41}$ Patch tests are performed with the application of standardized substances in the patient's upper back. The results are interpreted after 48 and 96 hours. ${ }^{46,47}$ This test must be performed to confirm the clinical diagnosis, to know the prevalence of sensitizing agents and for medical-legal reasons. A positive patch test is only relevant in the event of a causal relationship between the positive substances and the $\mathrm{CD}$. To characterize OD, the reaction can be related to a previous sensitization or associated with the patient's current clinical condition and activity. 


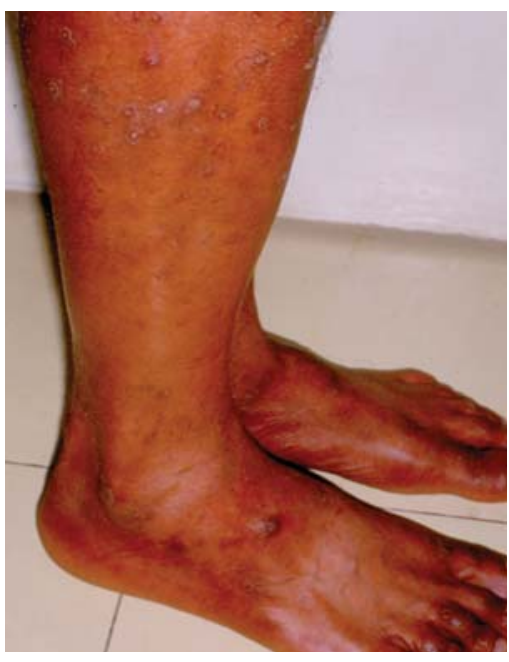

FIGURE 8: Allergic contact dermatitis caused by chrome and rubber present in the IPE of a chrome worker

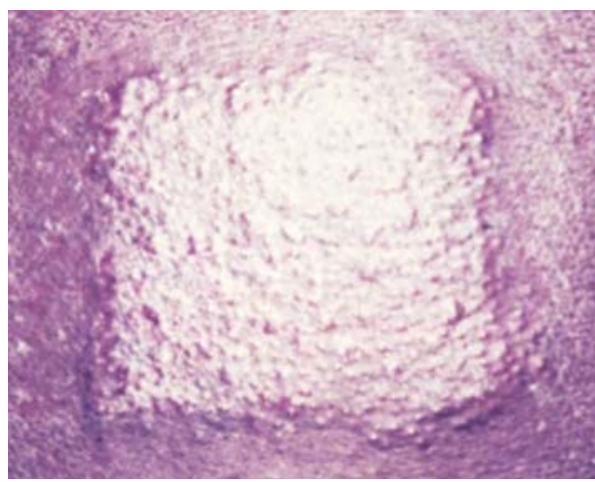

Figure 9: Positive patch test for potassium bicromate

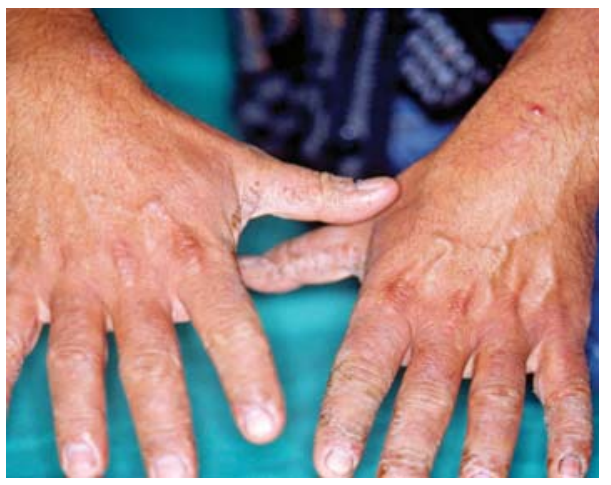

Figure 10: Allergic contact dermatitis caused by cutting fluids

In the cleaning sector, tests are performed with solutions diluted at $1 \%$ or $2 \%$ to avoid the irritant effect. In the metallurgical sector, PTs with new oils may yield negative results and tests with previously used oils, containg preservative additives (corrosion inhibitors and antimicrobial) may yield positive results. Both new and previously used oils can cause irritation. Patch tests with food apllied to healthy skin can be negative.

Prick-tests can be positive for latex, vegetables, and drugs. ${ }^{8}$
The ingestion test can be negative for ACD caused by food, due to cooking or action of gastric juices.

The performance of mycologic and bacteriologic exams may be necessary. Histopathologic examination of the cutaneous lesion may be relevant in the diagnosis of $\mathrm{OD}$; in $\mathrm{CD}$ it is not as specific as in eczemas, but it can help distinguish it from other dermatoses.

These exams show the importance of a correct diagnosis of OD.

\section{DIFFERENTIAL DIAGNOSIS}

These are the differential diagnoses typical of each OD.

Differential diagnoses for $\mathrm{CD}$ are other eczemas (atopic, microbial, nummular, stasis, neurodermitis, dishydrosis), psoriasis, and infections.

\section{TREATMENT}

Wrong diagnoses of occupational relationship and iatrogenies are disastrous for the patient, companies, and governmental organs. The identification of and withdrawal from the causal agent are extremely important measures. ${ }^{48,49}$ Treatment must be clearly advised. Names of the products and substances that the patient cannot be exposed to must be given to the individual in written form. Early treatment may lower the evolution time of lesions and avoid complications. Individual protective equipment, secondary infections and drugs used by the patient may lead to irritation or sensitization. Moreover, self-induced dermatosis masks and worsen OD.

Treatment depends on the extension and intensity of lesions. In acute lesions, that is, exudative, compresses with boric acid solution at $2 \%$ or $3 \%$ or potassium permanganate at 1:40,000 and corticoid creams should be used. In the localized forms of chronic OD, that is, with scaling and lichenificated lesions, the use of creams and ointments with corticoid at various percentages is recommended, based on the affected area. In extensive lesions, systemic corticoids are used, preferably prednisone, in initial doses of $0.5 \mathrm{mg}$ to $1 \mathrm{mg} / \mathrm{kg} / \mathrm{day}$, with gradual reduction. If there is secondary infection, topic and/or systemic antibiotics should be associated. Antihystaminic drugs for systemic use with sedative effects can be used to treat pruritus. Occupational infections are treated according to each etiologic agent. Cancers associated with professional activities are treated in accordance with each histologic type and tumoral staging.

Occupational dermatosis that leads to disability requires professional readaptation, with medical, vocational and psicotechnical orientation. 


\section{PREVENTION}

Prevention measures are extremely important to avoid OD. Companies should adopt collective prevention measures, such as periodical medical exams and orientation to workers to avoid relapses and the development of new OD cases. This disorder causes discomfort to the worker, professional disability, role changes, production and earnings reduction to the worker and company, and increase of medical and social welfare costs.

Personal hygiene must be done carefully and the use of emollients is indicated. Clothing should be kept clean. The areas of the body contaminated with irritants should be washed immediately and moisturized with fragrance-free creams. The most important orientation for the prevention of $\mathrm{CD}$ is the withdrawal of the irritant or allergen. In relation to $\mathrm{OD}$, the use of appropriate IPE (boots, hats, masks, aprons, and gloves), especial clothing, and awareness about personal hygiene can be emphasized. Barrier creams are often used, although their efficacy is questioned. 18 They should be used before the development of dermatitis, since their ingredients may cause ICD and ACD, especially if used in the affected skin. ${ }^{50}$ Photoprotection with clothing and topical photoprotectors are essential in individuals exposed to UV radiation.

The use of proper gloves is necessary in the prevention of $\mathrm{OD}$ (except in activities where manual dexterity is necessary and when the use of gloves may increase work accident risks). Individuals allergic to rubber should use vinyl or polyurethane gloves.
Those allergic to latex should use latex-free gloves and individuals allergic to acrillate should use nitrile gloves.

Despite the beneficial effects of the association between individual protective measures and education, there is the need to add ferrous sulphate to cement, which downgrades hexavalent chrome to the less-sensitizing trivalent chrome, in the prevention of ACD caused by chrome in civil construction workers. 51

A better knowledge of the epidemiology of OD may lead to preventive strategies that reduce the incidence of this common health problem. ${ }^{9}$

\section{PROGNOSIS}

Prognosis is variable because there are many types of occupational dermatoses and each one has its own prognosis. Allergic contact dermatitis has a worse prognosis than ICD. The chronicity of the condition is more frequent in the allergy to chrome and nickel. ${ }^{52}$ Morbidity is often high, especially in relation to quality of life associated with the chronic types of the disease. Many cases of OD lead to temporary or definitve work disability. ${ }^{53}$ Contact dermatitis can become chronic and/or relapse, with mortality rates next to zero. The clinical evolution of infections and cancers associated with professional activities will be typical of each kind. They usually have high morbidity and in some of these cases mortality rates can be significant. 


\section{REFERENCES}

1. Alchorne AOA, Alchorne MMA. Dermatoses ocupacionais. In: Borges DR, Rothschild HA, eds. Atualização terapêutica: manual prático de diagnóstico e tratamento. 22 ed. São Paulo: Artes Médicas; 2007. p. 252-3.

2. Ali AS. Dermatoses ocupacionais. In: Ferreira MJ, ed. Saúde no trabalho. São Paulo: Roca; 2000. p. 176-226.

3. Ali SA. Dermatoses ocupacionais. São Paulo: FundaCentro; 2001.

4. Ali SA, Oliveira HR. Dermatoses ocupacionais / Ministério da Saúde, Secretaria de Atenção à Saúde, Departamento de ações programáticas estratégicas. Brasília: Editora do Ministério da Saúde; 2006. (Série A. Normas e Manuais Técnicos - Saúde do Trabalhador).

5. Sampaio SAP, Rivitti EA. Dermatoses ocupacionais. In: Sampaio SAP, Rivitti EA, eds. Dermatologia. 3 ed. São Paulo: Artes Médicas; 2007. p. 1367 - 75.

6. Alchorne AOA, Alchorne MAA. Dermatoses ocupacionais. In: Lopes AC, ed. Diagnóstico e tratamento. São Paulo: Manole; 2006. p. 543.

7. Trindade MAB, Alchorne AOA, Maruta CW. Dermatoses ocupacionais. In: Lopes AC, ed. Tratado de clínica médica. São Paulo: Roca; 2006. p.271-.82.

8. Alchorne AOA, Alchorne MMA, Macedo MS. Dermatoses Ocupacionais. In: Schor N, ed.; Rotta O, coord. Guias de Medicina Ambulatorial e Hospitalar da UNIFESP - EPM. Guia de Dermatologia Clínica, Cirúrgica e Cosmiatrica. Barueri: Manole; 2008. p. 205-12.

9. Keegel T, Moyle M, Froen K, Nixon R. The epidemiology of occupational contact dermatitis (1990 - 2007): a systematic review. Intern J Dermatol. 2009; 48: 571 - 8 .

10. Diepgen TL, Coenrads PJ. The epidemiology of occupational contact dermatitis. In: Kanerva L, Elsner P, Wahlberg JE, Maibach HI, ed. Handbook of occupational dermatology. Heidelberg: SpringerVerlag; 2000. p. 1.

11. Kalimo $K$, Lammintausta $K$. The role of atopy in working life. In: Kanerva L, Elsner P, Wahlberg JE, Maibach HI, ed. Handbook of occupational dermatology. Heidelberg: Springer-Verlag; 2000.

12. Uter W, Kanerva L. Physical causes - heat, cold and other atmospheric factors. In: Kanerva L, Elsner P, Wahlberg JE, Maibach HI, ed. Handbook of occupational dermatology. Heidelberg: SpringerVerlag; 2000. p. 148.

13. Angelini G. Occupational dermatitis artefacta. In: Kanerva L, Elsner P, Wahlberg JE, Maibach HI, ed. Handbook of occupational dermatology. Heidelberg: Springer-Verlag; 2000. p. 141.

14. Alchorne AOA, Macedo MS. Dermatite de contato. In: Lopes AC, ed. Diagnóstico e Tratamento. São Paulo: Manole; 2006. p. 423.

15. Frosch PJ, Menne T, Lepoittevin JP. Contact dermatitis. 4th ed. Berlim: Springer; 2006.

16. Alchorne AOA, Alchorne MMA. Dermatoses alérgicas. In: Borges DR, Rothschild HA, eds. Atualização terapêutica: manual prático de diagnóstico e tratamento. 22 ed. São Paulo: Artes Médicas;
2007. p. 206-11

17. Guin JD. Practional contact dermatitis: a handbook for the practioner. New York: McGraw-Hill; 1995.

18. Li LY, Cruz Júnior PD. Allergic contact dermatitis: pathophysiology applied to future therapy. Dermatol Ther. 2004;17:219-23.

19. Rietschel RL, Fowler JF. FISHER's Contact Dermatitis. 5th ed. Philadelphia: Lippincot Williams \& Wilkins; 2001.

20. Alchorne AOA, Macedo MS. Dermatite de contato. In: Lopes AC, ed. Diagnóstico e tratamento. São Paulo: Manole; 2006. v. 2. p. 423-8.

21. Alchorne AOA, Alchorne MMA, Macedo MS. Dermatite de Contato. In: Schor N, editor. Rotta O, coordenador do Guia. Guias de Medicina Ambulatorial e Hospitalar da UNIFESP - EPM. Guia de Dermatologia Clínica, Cirúrgica e Cosmiatrica. Barueri: Manole; 2008. p. 195-203.

22. Basketter DA, Evans P, Gerberick GF, Kimber IA. Factors affecting thresholds in allergic contact dermatitis: safety and regulatory considerations. Contact Dermatitis. 2002;47:1-6.

23. Alchorne AOA, Macedo MS. Fitodermatoses. In: Schor $\mathrm{N}$, ed. Rotta O, coord. Guias de Medicina Ambulatorial e Hospitalar da UNIFESP - EPM. Guia de Dermatologia Clínica, Cirúrgica e Cosmiatrica. Barueri: Manole; 2008. p. 223-6.

24. Sampaio SAP, Rivitti EA. Erupções eczematosas. In: Sampaio SAP, Rivitti EA, eds. Dermatologia. 3 ed. São Paulo: Artes Médicas; 2007. p. 189 - 226.

25. Costa EB, Alchorne AOA. Fotodermatoses. In: Schor N, Ed; Rotta O, coord. Guias de Medicina Ambulatorial e Hospitalar da UNIFESP - EPM. Guia de Dermatologia Clínica, Cirúrgica e Cosmiatrica. Barueri: Manole; 2008. p. 227-31.

26. Souza PC, Alchorne AOA. Urticária. In: Schor N, ed; Rotta O, coord. Guias de Medicina Ambulatorial e Hospitalar da UNIFESP - EPM. Guia de Dermatologia Clínica, Cirúrgica e Cosmiatrica. Barueri: Manole; 2008. p. 219-22.

27. Alchorne AOA, Trindade MAB, Maruta CW. Dermatoses ocupacionais. In: Ramos-e-Silva M, Castro MCR, editoras. Fundamentos de Dermatologia. Rio de Janeiro: Atheneu; 2008. p. 587-96.

28. Pigatto PD, Bigardi AS. Occupational skin granulomas. In: Kanerva L, Elsner P, Wahlberg JE, Maibach HI. ed. Handbook of occupational dermatology. Heidelberg: Springer-Verlag; 2000. p. 135.

29. Conde-Salazar LG, Alayón AA. Dermatosis profesionales. Madrid: Signament Edicions; 2000.

30. Geier J, Schnuch A. A comparision of contact allergies amongy construction and nonconstruction workers attending contact dermatitis clinics in Germany results of the information network of Departaments of Dermatology from November 1989 to July 1993. Am J Contact Dermat. 1995; 6:86-94.

31. Alchorne AOA, Calafiori JR, Kitamura S, Wakamatsu CT. Alguns aspectos das dermatoses profissionais pelo cimento na construção civil. Rev Bras Saúde Ocup. 1975;11(III): 1 -12. 
32. Rietschel RL, Fowler Jr JF. Fisher's contact dermatitis. Ontario: BC Decker Inc; 2008.

33. Skogstad M, Levy F. Occupational irritant contact dermatitis and fungal infection in construction workers. Contact Dermatitis. 1994;31:28-30.

34. Pérez AG, Conde-Salazar L, Camarasa JMG. Tratado de dermatosis profesionales. Madrid: Eudema Universidad/ Manuales; 1987.

35. Shaffer MP, Belsito DV. Alergic contact dermatitis from glutaraldehyde in health - care workers. Contact Dermatitis. 2000;43:150.

36. Anderson BE. Mixed dialkyl thioreas. Dermatitis. 2009; 1:3-5.

37. Crotlin E, Kullavanijaya P. Hand dermatitis in hairdressers. Acta Derm Venereol. 1979; 59:48.

38. Mortz CG, Andersen KE. New aspects in allergic contact dermatitis. Curr Opin Allergy Clin Immunol. 2008;8:428-32.

39. Schnuch A, Uter W. The role of clinical epidemiology in the study of occupational contact dermatitis. In: Kanerva L, Elsner P, Wahlberg JE, Maibach HI, ed. Handbook of Occupational Dermatology. Heidelberg: Springer-Verlag; 2000. p. 17.

40. Belliboni NB. Considerações sobre as causas mais comuns de dermatoses ocupacionais em São Paulo (698 casos). Rev Bras Saúde Ocup. 1979;7:30 - 2.

41. Marks Jr JG, Elsner P, DeLeo V. Contact \& Occupational Dermatology. 3 ed. St. Louis: Mosby; 2002.

42. Mendes E. Alergia no Brasil. Alergenos regionais e imunoterapia. São Paulo: Editora Manole Ltda; 1989. p. 186.

43. Lovell CR. Plants and the skin. London: Blackwell Scientific Publications; 1993. p. 217.

44. Avalos J, Maiback HI. Botany Dermatology. United States of America: Clinical \& Basic Science series; 2000. p. 40

45. Adams RM. Occupational skin disease. 3rd ed. Philadelphia: W. B. Saunders Company; 1999. p. 357.

46. Marks Jr JG, Belsito DV, DeLeo V, et al. North American
Contact Dermatitis Group patch-test results, 19961998. Arch Dermatol. 2000;136:272-3.

47. Macedo MS, Alchorne AOA. Testes Alérgicos. In: Schor N, editor. Rotta O, coordenador do Guia. Guias de Medicina Ambulatorial e Hospitalar da UNIFESP - EPM. Guia de Dermatologia Clínica, Cirúrgica e Cosmiatrica. Barueri: Manole; 2008. p. 105 - 6.

48. Cohen DE, Heidary N. Treatment of irritant and allergic contact dermatitis. Dermatol Ther. 2004; 17:334-40.

49. Pontes de Carvalho LC, Rios JBM. Dermatite de Contato - Diagnóstico e Tratamento. Rio de Janeiro: Revinter; 2004.

50. Lushniak B, Mathias CG, Taylor JS. Barrier creams: fact or fiction. Am J Contact Dermatol. 2003;14:97-9.

51. Kanerva L, Elsner P, Wahlberg JE, Maibach HI Handbook of Occupational Dermatology. Heidelberg: Springer-Verlag; 2000.

52. Bourke J, Coulson I. English J. British Association of Dermatologists. Guidelines for care of contact dermatitis. Br J Dermatol. 2001;145:877-85.

53. Grupo Brasileiro de Estudo em Dermatite de Contato (GBEDC). Departamento de Alergia da Sociedade Brasileira de Dermatologia. Estudo multicêntrico para elaboração de uma bateria-padrão brasileira de teste de contato. An Bras Dermatol. 2000;75:147-56.

ENDEREÇO PARA CORRESPONDÊNCIA / MAILING ADDRESS: Alice de Oliveira de Avelar Alchorne Rua Iraúna, 469 04518060 São Paulo, SP - Brasil Tel./Fax: $551141273755 \quad 551159042447$

E-mail: a.alchorne@terra.com.br sis. An Bras Dermatol. 2010;85(2):137-47. 


\section{QUESTIONS}

1) It is wrong to state the following about noneczematous occupational dermatosis:
a) It can present erythematous-polymorphous lesions - simile.
b) Perfumes, colorings, wood and laundry detergent are causes of hyperchromic contact dermatitis
c) They occur frequently
d) Rubber may cause keratotic lesions

2) Occupational dermatosis may be caused by:
a) Metals, acids, alkalis, aromatic hydrocarbons, arsenic
b) Lubricating and cutting oils
c) Viruses, bacteria, fungi, parasites, plants, animals
d) All of the above

3) It is wrong to state the following about occupational skin cancer:
a) physical oncogenic agents: ionizing and non-ionizing radiations (ultraviolet and infrared rays)
b) Chemical oncogenic agents: inorganic arsenic, aromatic hydrocarbons, nitrosamines
c) Biological oncogenic agents: HPV virus
d) It is easy to establish a causal relationship

4) Occupational dermatosis may be caused by the following physical agents:
a) Radiation
b) Trauma, vibration, and pressure
c) Heat, cold
d) All of the above

5) It is wrong to state the following about the phisiopathology of occupational dermatosis:
a) Dermatitis artefacta may be provoked for the obtention of a benefit
b) The inflammatory process of ICD starts when the sensitizing agent in contact with the skin causes a lesion in the corneal layer, leading to an increase in permeability and entry of products that damage the keratinocytes
c) In ACD, the inflammatory reaction is of immunological type II (cytotoxic)
d) The etiopathogeny of ACD is divided into three phases a) induction; b) elicitation; c) resolution

6) Mark the wrong alternative:
a) Elaioconyosis does not occur in metallurgical and mechanical workers
b) Chloracne is caused by the industrial use of chlorate hydrocarbons
c) Basal cell and spinocellular carcinomas may be considered occupational dermatoses
d) Barber's disease (pilous fistula) is a foreign body granuloma caused by hair

7) It is wrong to state the following about occupational dermatoses:

a) In the metallurgical industry, the most common causes of OD are cutting fluids and galvanoplasty substances

b) In the food sector industry, occupational dermatosis may be caused by contact with irritative and sensitizing agents and humidity

c) In the area of health, occupational dermatosis more frequently affects the hand

d) In hairdressers' assistants and apprentices, ACD is more frequent than ICD.

8) It is wrong to state the following about occupational dermatology preventive measures:

a) Patients allergic to acrylate should use latex gloves

b) Patients allergic to rubber should use vinyl or polyurethane gloves

c) The most important orientation in the prevention of occupational contact dermatitis is withdrawal of the irritant or allergen

d) Patients allergic to latex should use vinyl, polyurethane or latex-free gloves.

9) It is wrong to state that:

a) The ingredients of barrier creams may case ICD and/or ACD

b) Barrier creams are used in the topical treatment of contact dermatitis

c) In addition to topical photoprotectors, the use of appropriate clothing is necessary to avoid ultraviolet radiation

d) Collective prevention measures implemented by companies are effective in the prevention of occupational dermatoses

10) It is wrong to state the following about the beauty sector:

a) It is the second largest group in number of workers in Brazil

b) Thioglycolate is used in hair dyes

c) Allergic contact dermatitis caused by henna tattoos may be due to paraphenylenediamine

d) Amonium persulphate is an irritative and sensitizing agent

11) It is wrong to state the following about ACD:

a) It affects nearly $80 \%$ of professional hairdressers

b) It occurs after an early variable sensitization phase

c) It is common in civil construction

d) The main allergens in civil construction are metals 
12) It is correct to state the following about the laboratory diagnosis of occupational dermatoses:

a) The patch test is the main laboratory resource to confirm the diagnosis of $\mathrm{CD}$

b) The interpretation of the patch test results is done 20 to 30 minutes after the application of the allergens to the skin

c) The prick test is a useful test in the diagnosis of ACD

d) Histopathologic examination is useful to differentiate between irritative and allergic contact dermatitis

13) Mark the incorrect answer:

a) The main differential diagnoses for contact dermatitis are other eczemas, psoriasis, infection, and dermatitis artefacta

b) Secondary infections and sequelas are complications of occupational dermatosis

c) Among occupational dermatoses, contact dermatitis are always eczematous

d) The topical treatment of contact dermatitis depends on elementary lesions present in the skin

14) It is wrong to state:

a) The use of systemic corticosteroids is indicated to treat widespread occupational contact dermatitis

b) In occupational dermatoses with secondary infection, topical and/or systemic antibiotics can be used

c) Antihistaminic drugs are useful in the treatment of contact dermatitis because they are mediated by IgE

d) Nitrosamine is an oncogenic agent

15) It is wrong to state:

a) Rubber and cement are the greatest occupational risks for men

b) Occupational dermatoses are less frequent in the elderly

c) Occupational dermatoses are more frequent in women

d) Occupational dermatoses are less frequent in the yellow race

16) It is wrong to state:

a) Contact urticaria caused by latex is mediated by IgE

b) Occupational dermatoses are less frequent in black individuals

c) Occupational ACD is less frequent than ICD

d) The most common allergens for women are cosmetics

17) The most frequent agents that cause occupational dermatoses are:

a) Physical

b) Viral and fungal c) Chemical

d) Plants

18) It is wrong to state that the most frequent occupational dermatoses in the different work sectors are:

a) In the cleaning sector industry, irritative contact dermatitis

b) Allergic contact dermatitis caused by drugs in the health area

c) In the food sector industry, ICD, ACD, and phytodermatosis

d) In civil construction, ICD and ACD caused by cement

19) For the patch test in the food sector industry, the concentration used is:
a) $10 \%$ to $12 \%$
b) $22.5 \%$ to $25 \%$
c) $1 \%$ to $2 \%$
d) $0.025 \%$ to $0.5 \%$

20) New oil used in metallurgy may yield negative patch test results and used oil can yield positive results because:

a) The used oil may be contaminated with bacteria

b) Antimicrobial agents are used as preservatives in used oil

c) Used oil may be contaminated with fungi

d) Used oil may suffer oxidation

Answer key

Immunossupressive agents in Dermatology. 2010; 85(1):9-22.

$\begin{array}{llll}1 & \text { b } & 11 & \text { c } \\ 2 & \text { a } & 12 & \text { d } \\ 3 & \text { d } & 13 & \text { d } \\ 4 & \text { c } & 14 & \text { b } \\ 5 & \text { c } & 15 & \text { b } \\ 6 & \text { c } & 16 & \text { c } \\ 7 & \text { a } & 17 & \text { d } \\ 8 & \text { b } & 18 & \text { a } \\ 9 & \text { d } & 19 & \text { c } \\ 10 & \text { b } & 20 & \text { c }\end{array}$

\section{Papers}

Information for all members: The EMC$\mathrm{D}$ questionnaire is now available at the homepage of the Brazilian Annals of Dermatology: www.anaisdedermatologia.org.br. The deadline for completing the questionnaire is 60 days from the date of online publication. 